OPEN ACCESS

Edited by:

Niels Olsen Saraiva Camara,

University of São Paulo, Brazil

Reviewed by:

Sandra Helena Poliselli Farsky,

University of São Paulo, Brazil

José C. Alves-Filho,

University of São Paulo, Brazil

Philippe Georgel,

Strasbourg University, France

${ }^{*}$ Correspondence:

Celine A. Beamer

celine.beamer@umontana.edu

Specialty section: This article was submitted to

Molecular Innate Immunity,

a section of the journal

Frontiers in Immunology

Received: 02 October 2015 Accepted: 01 February 2016 Published: 15 February 2016

Citation:

Beamer GL, Seaver BP, Jessop F, Shepherd DM and Beamer CA (2016)

Acute Exposure to Crystalline Silica Reduces Macrophage Activation in Response to Bacterial Lipoproteins.

Front. Immunol. 7:49.

doi: 10.3389/fimmu.2016.00049

\section{Acute Exposure to Crystalline Silica Reduces Macrophage Activation in Response to Bacterial Lipoproteins}

\author{
Gillian L. Beamer ${ }^{1}$, Benjamin P. Seaver ${ }^{2}$, Forrest Jessop ${ }^{2,3}$, David M. Shepherd ${ }^{2}$ and \\ Celine A. Beamer ${ }^{2,4 *}$
}

${ }^{1}$ Department of Infectious Diseases and Global Health, Cummings School of Veterinary Medicine, Tufts University, North Grafton, MA, USA, ${ }^{2}$ Department of Biomedical and Pharmaceutical Sciences, University of Montana, Missoula, MT, USA, ${ }^{3}$ Center for Environmental Health Sciences, Missoula, MT, USA, ${ }^{4}$ Center for Biomolecular Structure and Dynamics, Missoula, MT, USA

Numerous studies have examined the relationship between alveolar macrophages (AMs) and crystalline silica $\left(\mathrm{SiO}_{2}\right)$ using in vitro and in vivo immunotoxicity models; however, exactly how exposure to $\mathrm{SiO}_{2}$ alters the functionality of $\mathrm{AM}$ and the potential consequences for immunity to respiratory pathogens remains largely unknown. Because recognition and clearance of inhaled particulates and microbes are largely mediated by pattern recognition receptors (PRRs) on the surface of AM, we hypothesized that exposure to $\mathrm{SiO}_{2}$ limits the ability of $\mathrm{AM}$ to respond to bacterial challenge by altering PRR expression. Alveolar and bone marrow-derived macrophages downregulate TLR2 expression following acute $\mathrm{SiO}_{2}$ exposure (e.g., 4 h). Interestingly, these responses were dependent on interactions between $\mathrm{SiO}_{2}$ and the class $\mathrm{A}$ scavenger receptor CD204, but not MARCO. Furthermore, $\mathrm{SiO}_{2}$ exposure decreased uptake of fluorescently labeled $\mathrm{Pam}_{2} \mathrm{CSK}_{4}$ and $\mathrm{Pam}_{3} \mathrm{CSK} 4$, resulting in reduced secretion of IL-1 $\beta$, but not IL-6. Collectively, our data suggest that $\mathrm{SiO}_{2}$ exposure alters AM phenotype, which in turn affects their ability to uptake and respond to bacterial lipoproteins.

Keywords: lung, inflammation, mouse, scavenger receptor, toll-like receptor, bacterial susceptibility

\section{INTRODUCTION}

Silicon dioxide, also known as silica, is one of the most common elements on earth, yet its inhalation can result in acute lung injury and ongoing inhalation can result in permanent lung damage due to deposition of particles in the lung. Silicosis is a progressive, disabling, and often-fatal lung disease resulting from the inhalation of crystalline silica $\left(\mathrm{SiO}_{2}\right)$ particles over prolonged periods of time. Silicosis occurs as the result of exposure through occupation (e.g., construction, mining), recreation (e.g., pottery), or environment (e.g., soil). Inhalation of $\mathrm{SiO}_{2}$ particles causes a granulomatous inflammatory response that progresses to interstitial fibrosis as well as systemic immune deficits $(1-5)$. There is no cure for silicosis, and treatment options are limited. Although significant efforts have been made through industrial hygiene standards to control ambient dust in the workplace, silicosis remains a prevalent health problem throughout the world, particularly in developing nations (6).

In addition to its importance as an occupational hazard, inhalation of $\mathrm{SiO}_{2}$ predisposes workers to bacterial infections, impairs lung defense mechanisms, and significantly shortens worker 
lifespans - particularly in less-advanced countries and among disadvantaged persons in developed nations $(1,7)$. In particular, $\mathrm{SiO}_{2}$-exposed workers, with or without silicosis, are at increased risk for tuberculosis and non-tuberculous mycobacteria-related diseases $(5,8,9)$. Previous studies suggest that the acute and accelerated forms of silicosis exhibit the highest prevalence of silicotuberculosis (1), and that the development of Mycobacterium tuberculosis (Mtb) infection is directly dependent on the collective $\mathrm{SiO}_{2}$ exposure $(5,8,10)$. Indeed, $\mathrm{SiO}_{2}$ exposure results in a threefold or greater risk of developing pulmonary Mtb infections. Similarly, recent studies demonstrate that acute exposure to silica nanoparticles increases the susceptibility of mice to Pseudomonas aeruginosa-induced pneumonia (11).

Alveolar macrophages (AMs) play a critical role in the ongoing cross-talk between innate and adaptive immune responses in the lung and are the typical host cell for an array of pathogens such as bacterial infections (e.g., Mtb) and many airborne particulates (e.g., $\mathrm{SiO}_{2}$ ). In macrophages, formation and activation of the NLRP3 inflammasome are an important mechanism mediating the inflammatory response to numerous particulates, including nanoparticles, silica, MSU crystals, asbestos, and urban particulate matter, resulting in promotion of IL- $1 \beta$ release (12-15). Macrophages not only initiate the inflammatory process to $\mathrm{SiO}_{2}$ (16) but also play an important role in host resistance to bacterial infections, including Mtb (17). Moreover, numerous adverse effects on macrophage function have been described following exposure to $\mathrm{SiO}_{2}(18-27)$, suggesting that $\mathrm{SiO}_{2}$-mediated macrophage injury might impair host defense and increase susceptibility to infection. The current view is that $\mathrm{SiO}_{2}$ "damages" macrophages or alters their phenotype, thereby inhibiting their ability to phagocytose and kill bacteria $(19,28)$; however, the molecular mechanisms underlying this predisposition remain unknown.

Alveolar macrophages sense bacterial pathogens through pattern recognition receptors (PRRs) $(29,30)$ via the detection of highly conserved molecular structures, designated pathogenassociated molecular patterns (PAMPs) (31-33). Numerous families of PRRs exist, all of which recognize a different repertoire of PAMPs, including C-type lectin receptors, scavenger receptors (SRs), toll-like receptors (TLRs), NOD-like receptors, and RIGI-like receptors. Of these PRRs, TLRs $1 / 2,4$, and C-type lectin receptors have all been shown to mediate the in vitro recognition of $\mathrm{Mtb}$ and the cytokine response of macrophages is lower in the absence of these TLRs (34). It is clear that macrophages contribute to the lung response to $\mathrm{SiO}_{2}$ and to bacterial infections independently, and that these effects may be mediated through PRRs. Therefore, we investigated whether $\mathrm{SiO}_{2}$ exposure alters the expression of select PRRs on alveolar and bone marrowderived macrophages and assessed the ability of $\mathrm{SiO}_{2}$-exposed macrophages to uptake and respond to bacterial lipoproteins acting at TLR2/ 1 and TLR2/6.

\section{MATERIALS AND METHODS}

\section{Mice}

Breeding pairs of C57BL/6 (C57BL/6J, stock \#000664) mice were originally purchased from The Jackson Laboratory (Bar
Harbor, ME, USA); whereas breeding pairs of $\mathrm{MARCO}^{-1-}$ and $\mathrm{SRA}^{-/-}$mice on $\mathrm{C} 57 \mathrm{BL} / 6$ background were kindly provided by Dr. Lester Kobzik (Harvard School of Public Health, Boston, MA,

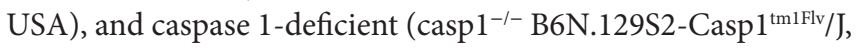
stock \#016621) mice (for experimental use) were kindly provided by Dr. Andrij Holian (University of Montana, Center for Environmental Health Sciences). All mice were maintained in the University of Montana Specific Pathogen-Free (SPF) Laboratory Animal Facility and both sexes used at 6-8 weeks of age. All animal use procedures were in accordance with NIH and University of Montana IACUC guidelines.

\section{Experimental Instillations}

Crystalline silica $\left(\mathrm{SiO}_{2}, 1.5-2 \mu \mathrm{m}\right)$ (Pennsylvania Glass Sand Corporation, Pittsburgh, PA, USA) was acid washed, dried, and determined to be free of endotoxin (data not shown). Mice were anesthetized with isoflurane and instilled via the intranasal (i.n.) exposure route with $25 \mu \mathrm{l}$ sterile saline (vehicle) or $1 \mathrm{mg} \mathrm{SiO}{ }_{2}$ suspended in $25 \mu \mathrm{l}$ of sterile saline $(35,36)$. Mice were then returned to their cages and monitored until mobility returned. Whole lung lavage samples were collected at 4,24 , and $72 \mathrm{~h}$, as well as 7 days following the initial instillation, as previously described $(37,38)$.

\section{Flow Cytometry}

Single cell suspensions from either whole lung lavages or bone marrow-derived macrophages were washed and re-suspended in $100 \mu$ l of purified rat anti-mouse CD 16/CD32 diluted 1:100 in PBS with $1 \%$ bovine serum albumin and $0.1 \%$ sodium azide $(\mathrm{PAB})$ for 15 min on ice to block non-specific Ab binding. Monoclonal Abs specific to CD11c redFluor 710 (clone \#N418, Tonbo Biosciences), F4-80 FITC (clone BM-8), DC-SIGN PE (clone \# 5H10), TLR2 eF450 (clone \# 6C2 eBiosciences), TLR4 PE-Cy7 (clone \# SA1521, Biolegend), TLR5 AF647 (clone \# ACT5), and TLR6 (clone \# $418601, \mathrm{R} \& \mathrm{D}$ Systems) to identify cell surface receptor density on live, F4- $80^{+} \mathrm{CD} 11 \mathrm{c}^{+} \mathrm{AMs}$ (23). Following titration of the individual antibodies in preliminary experiments, $1 \mu \mathrm{g}$ of each $\mathrm{Ab}$ was added per $10^{6}$ total cells and allowed to incubate for $30 \mathrm{~min}$ in the dark on ice, with agitation two to three times. Finally, cells were washed twice with PBS and re-suspended in $0.3 \mathrm{ml} \mathrm{PAB}$ on ice. Immediately before acquisition, $5 \mu$ l of propidium iodide solution (BioLegend) was added per $10^{6}$ total cells and allowed to incubate for $15 \mathrm{~min}$ prior to analysis. Cell acquisition and analysis were performed on a FACS Aria flow cytometer using FACS Diva software (version 6.1.2, Becton Dickinson), with the exception of Figure 4 - where cell acquisition and analysis was performed on a Attune NxT Accoustic Focusing Cytometer using Attune NxT software (version 2.2, Thermo Fisher Scientific). In the multicolor staining panels, positive/negative gates were set based on fluorescence minus one (FMO) controls and checked against single stained controls. Compensation of the spectral overlap for each fluorochrome was performed using compensation control beads (BD Biosciences).

\section{Generation and Stimulation of Bone Marrow-Derived Macrophages}

Bone marrow macrophages (BMM) were generated using murine recombinant macrophage colony-stimulating factor 
(50 ng/ml, U.S. Biological, Swampscott, MA, USA), as previously described $(37,39)$. By 7 days, cells were fully differentiated, $>75 \%$ confluent, and immune-positive for macrophage characteristics $\left(\mathrm{F} 4-80^{+} \mathrm{CD} 11 \mathrm{~b}^{+} \mathrm{MHC}\right.$ class $\left.\mathrm{II}^{\text {low }}\right)$, as assessed by flow cyometry (data not shown). Viability was determined to be $>90 \%$ by trypan blue exclusion staining prior to experimental manipulations. BMM were seeded at $10^{6} \mathrm{cells} / \mathrm{ml} /$ well of a 6 -well plate, immediately exposed to media alone (vehicle) or $50-100 \mu \mathrm{g} / \mathrm{ml} \mathrm{SiO}_{2}$, and allowed to incubate for 4 or $24 \mathrm{~h}$ at $37^{\circ} \mathrm{C}$. By $24 \mathrm{~h}$ at these exposure levels, $20 \%$ of the BMM exhibited signs of apoptosis and/or cell death using trypan blue exclusion and/or live dead dyes during flow cytometry experiments. Following stimulation, BMM were lightly scraped within the spent culture media, centrifuged, and the supernatant and cells separated for analysis.

\section{Confocal Microscopy and Quantification of Uptake of Rhodamine TLR Ligands}

Bone marrow macrophages $\left(1 \times 10^{6}\right.$ cells/eppendorf microfuge tube) were exposed to media alone (vehicle) or $50-100 \mu \mathrm{g} / \mathrm{ml}$ $\mathrm{SiO}_{2}$ on a rotisserie for $24 \mathrm{~h}$ at $37^{\circ} \mathrm{C}$. Macrophages were subsequently exposed to $0.5 \mu \mathrm{g} / \mathrm{ml}$ rhodamine conjugated $\mathrm{Pam}_{2} \mathrm{CSK}_{4}$ (TLR2/6 ligand) or $\mathrm{Pam}_{3} \mathrm{CSK} 4$ (TLR2/1 ligand) (Invivogen) for $2 \mathrm{~h}$. Cells were washed twice with PBS and were cytospun $\left(1 \times 10^{5}\right)$ onto glass slides, coverslipped with Prolong Gold with Dapi, and images collected on an Olympus Fluoview Confocal Imaging System. NIH Image J software or flow cytometry was used to analyze mean fluorescence intensity (MFI) and side scatter (SSC) properties of the BMMs to measure TLR ligand or $\mathrm{SiO}_{2}$ uptake (40).

\section{Cytokine ELISAs}

IL-1 $\beta$, TNF $\alpha$, IL-6, and IL-10 were measured in tissue culture supernatants using murine ELISA kits according to the manufacturer's instructions and assay procedure (R\&D Systems). Color development was assessed at $450 \mathrm{~nm}$ on a plate reader.

\section{Statistical Analysis}

For each parameter, the values for individual mice were averaged and the SD and SE calculated. The significance of the differences between the exposure groups was determined by $t$-test, oneway, or two-way ANOVA, in conjunction with Tukey's test for variance, where appropriate. All ANOVA models were performed with Prism software, version 4 . A $p$-value of $<0.05$ was considered significant.

\section{RESULTS}

\section{Differential Pattern Recognition Receptor Expression following Acute Silica Exposure}

Previous studies established that $\mathrm{SiO}_{2}$ alters the phenotype and function of AM, bone marrow-derived dendritic cells, and macrophages, and freshly isolated interstitial macrophages and dendritic cells $(23,39,41)$; however, these studies did not evaluate PRR expression on $\mathrm{AM}$ in response to $\mathrm{SiO}_{2}$. To test whether exposure of AMs in situ resulted in altered expression of PRRs,
C57Bl/6 wild-type mice were instilled with either saline (vehicle control) or $1 \mathrm{mg} \mathrm{SiO}$. Four hours after encountering $\mathrm{SiO}_{2}$ in the alveolus, flow cytometry confirmed that live (PI negative) $\mathrm{F} 4-80^{+} \mathrm{CD} 11 \mathrm{c}^{+} \mathrm{AMs}$ had taken up $\mathrm{SiO}_{2}$ particles via changes in SSC properties, and simultaneously downregulated their expression of TLR2 and TLR6, but not DC-SIGN, TLR4, or TLR5 (Figure 1, inset). Representative histograms illustrate the relative change in fluorescent intensity between AMs lavaged from the airways of saline (black line) vs. $\mathrm{SiO}_{2}$ (silver line) exposed $\mathrm{C} 57 \mathrm{Bl} / 6$ wild-type mice, compared to unstained controls (dashed line) (Figure 1).

In the murine model, TLR-2 in particular plays a crucial role in the cellular response to bacterial pathogens. Therefore, we evaluated whether $\mathrm{SiO}_{2}$ exposure downregulated TLR2 expression levels on live, $\mathrm{F} 4-80^{+} \mathrm{CD} 11 \mathrm{c}^{+} \mathrm{AMs}$ in a time-dependent manner in wild-type $\mathrm{C} 57 \mathrm{BL} / 6$ mice. $\mathrm{SiO}_{2}$ exposure reduced TLR2 expression on the surface of AMs by 86.4 and $32.9 \%$ relative to their corresponding saline controls at 4 and $24 \mathrm{~h}$, respectively. By contrast, $\mathrm{SiO}_{2}$ exposure increased TLR2 expression on the surface of AMs by $47.8 \%$ relative to the saline control at $72 \mathrm{~h}$. By 7 days after silica exposure, TLR2 expression on live, F4-80 ${ }^{+} \mathrm{CD} 11 \mathrm{c}^{+}$ AMs had returned to baseline (Figure 2A). Representative histograms illustrate the relative change in fluorescent intensity between saline (black line) and $\mathrm{SiO}_{2}$ (silver line) exposed mice at the indicated time point following exposure (Figure 2B).

\section{Silica-Induced Changes in TLR2 Expression Are Dependent on CD204, but Not Inflammasome Activation}

Previous studies from our laboratory established that the class A SRs CD204 and MARCO were important for the binding/ uptake of $\mathrm{SiO}_{2}$ and subsequent inflammatory response $(35,40)$. Therefore, we investigated the relationship between CD204 and MARCO, and $\mathrm{SiO}_{2}$-induced changes in TLR2 expression. Using bone marrow-derived macrophages as a model system (41), we demonstrate that $\mathrm{SiO}_{2}$-induced loss of TLR2 expression on F4 $-80^{+} \mathrm{CD} 11 \mathrm{~b}^{+}$macrophages was dependent on CD204, but not MARCO at $4 \mathrm{~h}$ (Figure 3A) and $24 \mathrm{~h}$ post-exposure (data not shown). Representative histograms illustrate the relative change in fluorescent intensity of TLR2 on the cell surface of media (black line) and $\mathrm{SiO}_{2}$ (silver line)-treated bone marrow-derived macrophages (Figure 3A). These results were confirmed using AMs lavaged from saline and $\mathrm{SiO}_{2}$-exposed $\mathrm{C} 57 \mathrm{Bl} / 6$ wild-type and CD $204^{-/-}$mice, at $4 \mathrm{~h}$ post-exposure (Figure $3 \mathrm{~B}$ ). Representative histograms illustrate the relative change in fluorescent intensity of TLR2 on the cell surface of live, F4-80+CD11 ${ }^{+}$AMs between saline (black line) and $\mathrm{SiO}_{2}$ (silver line) exposed mice (Figure 3B).

NLRP3 inflammasome activation and resultant IL- $1 \beta$ production by AMs is recognized as a significant mechanism underlying silicosis $(13,24,26,42)$. Because activation of the NLRP3 inflammasome converges on caspase 1 , which then contributes to the production and secretion of mature IL- $1 \beta$, we examined the contributions of inflammasome activation to $\mathrm{SiO}_{2}$-induced changes in TLR2 expression using caspase 1 -deficient (caspase $1^{-/}$) mice. Four hours following exposure, we show that $\mathrm{SiO}_{2}$-induced loss of TLR2 expression on live, F4- $80^{+} \mathrm{CD} 11 \mathrm{c}^{+} \mathrm{AM}$ occurs independent from NLRP3 inflammasome activation and secretion of IL-1 $\beta$ 

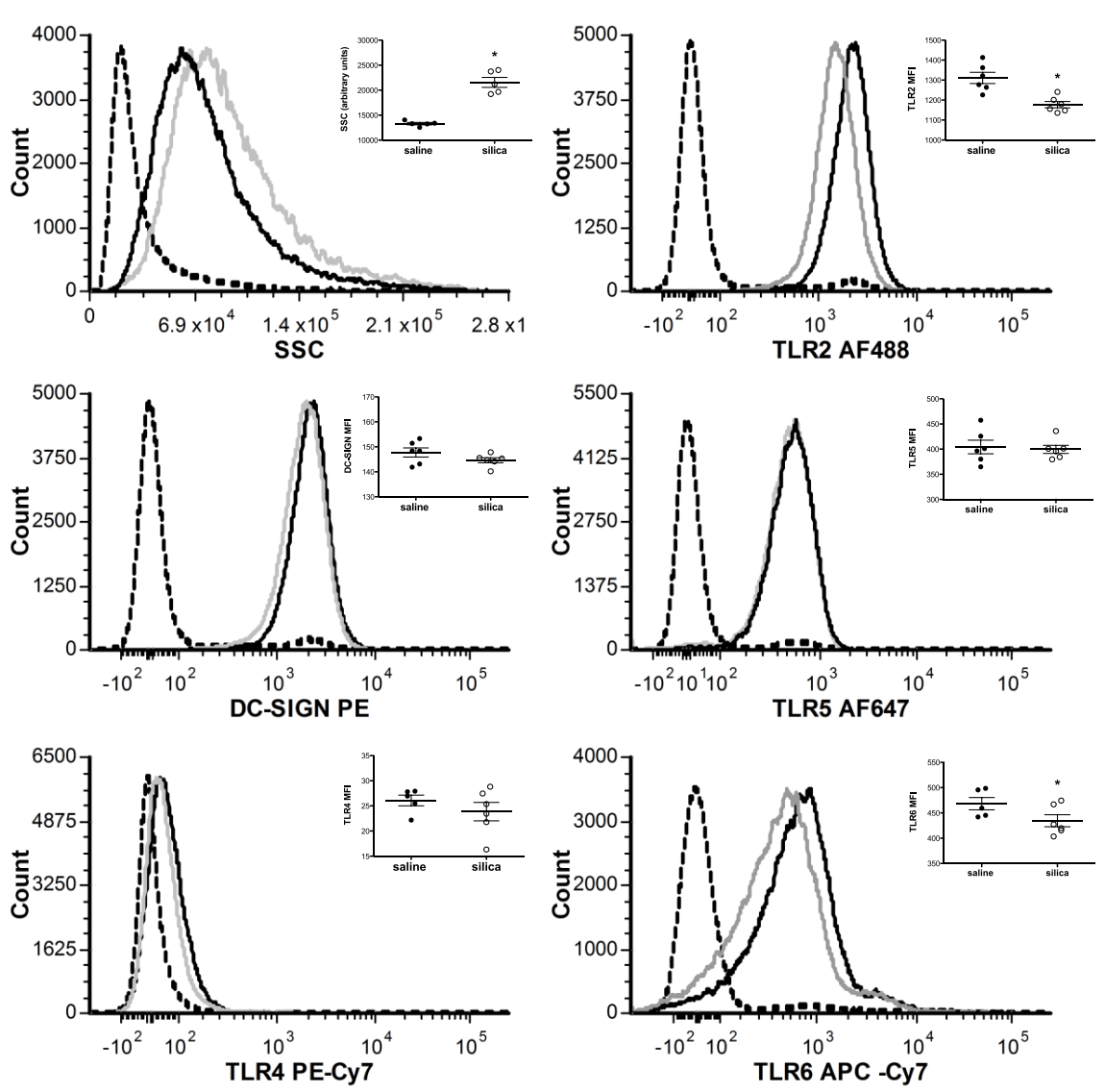

FIGURE 1 | Acute silica exposure selectively reduced TLR2 and TLR6 expression on F4-80+CD11c ${ }^{+}$alveolar macrophages. C57BI/6 wild-type mice were exposed to saline ( $25 \mu$ l, black line) or silica ( $1 \mathrm{mg}$, gray line) through intranasal aspiration. After $4 \mathrm{~h}$, whole lungs were lavaged and cells immunostained. Representative histograms from the flow cytometric analysis demonstrates concomitant uptake of $\mathrm{SiO}_{2}$ particles through increases in side scatter (SSC) measurements and decreased expression of TLR2 and TLR6 expression on alveolar macrophages (AMs) relative to saline control. By contrast, no change was observed in the cell surface expression of DC-SIGN, TLR4, or TLR5 on live, F4-80+CD11 $\mathrm{C}^{+} \mathrm{AMs}$ in response to $\mathrm{SiO}_{2}$. Scatter plots (inset) show the raw data in graphical form. Results are means $\pm \operatorname{SEM}(n=6)$. ${ }^{\star} p<0.05$ compared to saline.

(Figure 4A). Representative histograms demonstrate the relative change in fluorescent intensity of TLR 2 on the cell surface of live, $\mathrm{F} 4-80^{+} \mathrm{CD} 11 \mathrm{c}^{+}$AMs between saline (black line) and $\mathrm{SiO}_{2}$ (silver line) exposed $\mathrm{C} 57 \mathrm{Bl} / 6$ and caspase $1^{-/-}$mice (Figure 4B).

\section{Effects of Silica Exposure on the Uptake of TLR2/1 and TLR2/6 Ligands}

Because TLR2 cooperates with TLR6 in response to diacylated mycoplasmal lipopeptide and associates with TLR1 to recognize triacylated lipopetides, we next examined the ability of $\mathrm{SiO}_{2}$ exposed bone marrow-derived macrophages to take up fluorescently labeled bacterial cell wall components recognized by the TLR2/1 heterodimer $\left(\mathrm{Pam}_{3} \mathrm{CSK}_{4}\right)$ and TLR2/6 heterodimer $\left(\mathrm{Pam}_{2} \mathrm{CSK}_{4}\right)$ using a combination of flow cytometry and confocal microscopy. Flow cytometry demonstrated that $\mathrm{SiO}_{2}$ exposure reduced the uptake (e.g., MFI) of both the synthetic triacylated and synthetic diacylated lipoproteins recognized by TLR2/1 and TLR2/6 heterodimers, respectively, in both C57Bl/6 and CD204 ${ }^{-/-}$ derived cells (Figure 5A). This response was slightly dampened in $\mathrm{CD} 204^{-/-}$cells vs. $\mathrm{C} 57 \mathrm{Bl} / 6$ cells. Moreover, simultaneous measurements of SSC characteristics revealed comparable levels of $\mathrm{SiO}_{2}$ uptake across all exposure groups and mouse strains (Figure 5A), indicating similar levels of $\mathrm{SiO}_{2}$ exposure and uptake across treatment groups. Representative images collected via confocal microscopy support the observation of reduced uptake of fluorescently labeled TLR ligands in response to $\mathrm{SiO}_{2}$ exposure (Figure 5B). These changes were quantified by image analysis using NIH Image J and showed a similar reduction in uptake of fluorescently labeled diacylated and triacylated lipopetides into $\mathrm{SiO}_{2}$-exposed cells (data not shown).

\section{Silica Exposure Reduced IL-1 $\beta$ Levels in Response to Synthetic Triacylated and Synthetic Diacylated Lipoproteins In Vitro}

Given that the observed reduction in TLR expression correlated with a decrease in lipoprotein uptake, we next determined if this resulted in functional changes by analyzing the inflammatory response of $\mathrm{BMM}$ to $\mathrm{SiO}_{2}$ plus or minus synthetic triacylated and diacylated lipoproteins. We chose to focus on the trifecta of innate immune cytokines because of both lipoproteins are 


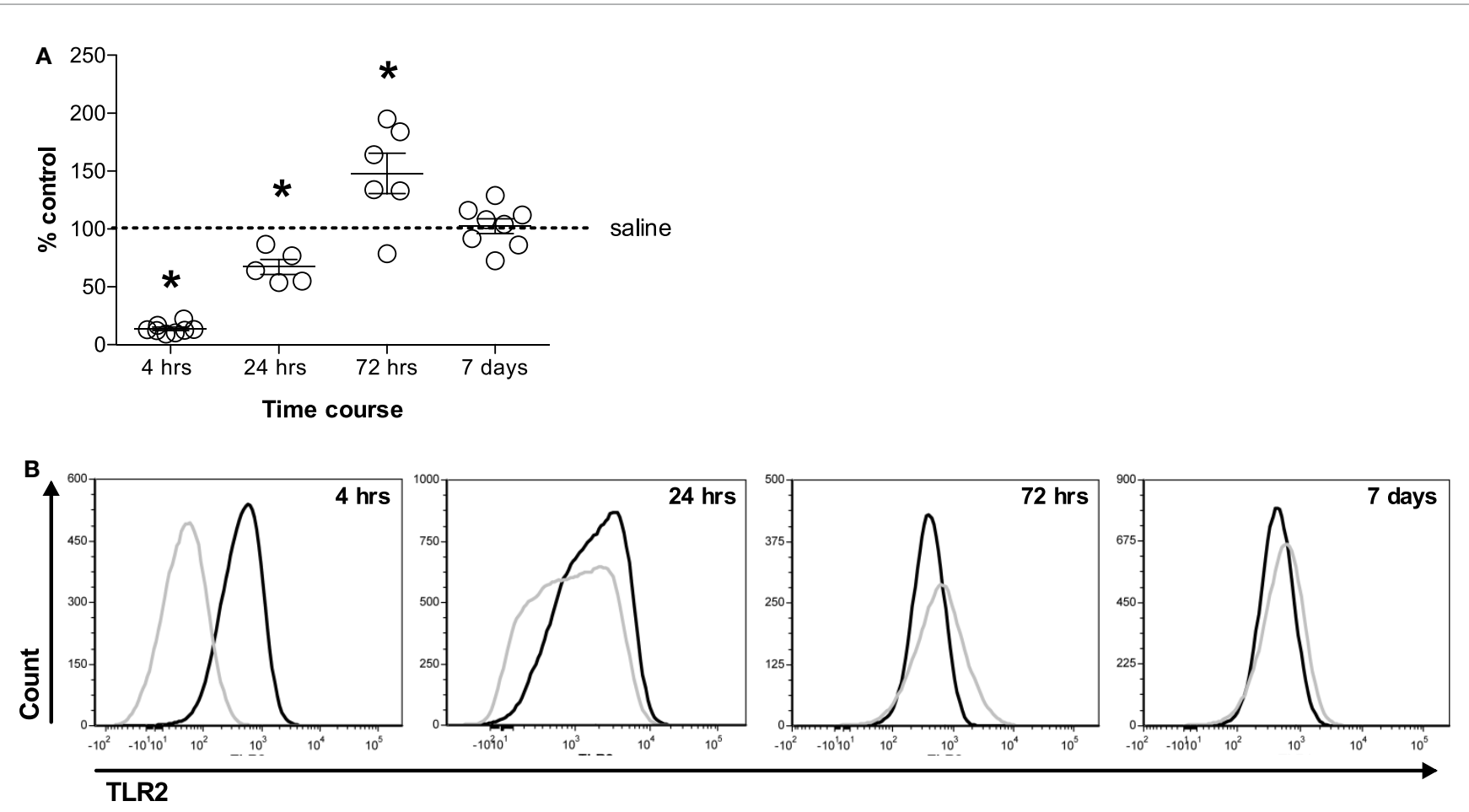

FIGURE 2 | Silica exposure altered TLR2 expression on F4-80+CD11c ${ }^{+}$alveolar macrophages. C57Bl/ 6 wild-type mice were exposed to saline (25 $\mu$ l) or silica (1 mg) through intranasal aspiration. After 4, 24, 72 h, and 7 days, whole lungs were lavaged and cells immunostained. (A) Flow cytometric analysis demonstrates decreased expression of TLR2 on live, F4-80+CD11 $\mathrm{C}^{+}$alveolar macrophages (AMs) at 4 and $24 \mathrm{~h}$, whereas TLR2 expression was increased on AMs at $72 \mathrm{~h}$. By contrast, no change was observed in the cell surface expression of TLR2 on AMs 7 days following exposure to SiO 2 . Results are presented as mean percent of control \pm SEM $(n=6-8)$. ${ }^{*} p<0.05$ compared to saline control. (B) Representative histograms from the flow cytometric analysis demonstrate changes in the cell surface expression of TLR2 as a function of time.

anticipated to induce the maturation and release of IL-1 $\beta$, and to trigger the release of TNF $\alpha$ and IL-6 (likely via the activation of NF-kb signaling pathways). As anticipated, bone marrow-derived macrophages recognized and responded to synthetic triacylated and diacylated lipoproteins by increasing levels of IL-1 $\beta$, TNF $\alpha$, and IL- 6 found in the tissue culture supernatant relative to media alone, whereas exposure to $\mathrm{SiO}_{2}$ alone resulted in little to no change (Figure 6). Although $\mathrm{SiO}_{2}$ exposure reduced the levels of IL-1 $\beta$ and TNF $\alpha$ present in the tissue culture supernatant in response to stimulation with either $\mathrm{Pam}_{2} \mathrm{CSK}_{4}$ or $\mathrm{Pam}_{3} \mathrm{CSK} 4$, it had no effect on the secretion of IL-6 (Figure 6). Furthermore, as a positive control, exposure to $\mathrm{SiO}_{2}$ plus $10 \mathrm{ng} / \mathrm{ml}$ LPS appears to have activated the Nlrp3 inflammasome, thus resulting in enhanced IL-1 $\beta$ secretion relative to either stimulus alone (Figure 6) and supporting the finding that TLR4 expression remains unchanged by $\mathrm{SiO}_{2}$ exposure. Finally, although we analyzed the tissue culture supernatants for the presence of IL-10, the levels detected were at or below the limit of detection of the assay.

\section{DISCUSSION}

Silicosis, the most prevalent of the pneumoconioses, is caused by inhalation of crystalline $\mathrm{SiO}_{2}$ particles. In addition to its importance as an occupational disease, silicosis or even exposure to $\mathrm{SiO}_{2}$ without established disease is associated with increased risk of developing many pulmonary and systemic comorbidities: chronic obstructive pulmonary disease, lung cancer, tuberculosis, non-tuberculous mycobacteria-related diseases, glomerulonephritis, rheumatoid arthritis, scleroderma, and other systemic autoimmune diseases. Although the epidemiological link between silicosis and tuberculosis has been acknowledged for decades, the cellular and molecular mechanisms underlying this increased risk remain largely unknown. As the first line of defense in the alveolar spaces, AM recognize and respond to inhaled pathogens and particulates, likely through interactions with PRRs, resulting in activation of NLRP3 inflammasome among many other signaling pathways. The primary objectives of this investigation were to (1) uncover if $\mathrm{SiO}_{2}$ modifies the profile of select PRRs expressed on macrophages and (2) examine the interactions between $\mathrm{SiO}_{2}$ exposed macrophages and $\mathrm{Pam}_{3} \mathrm{CSK}_{4}$ and $\mathrm{Pam}_{2} \mathrm{CSK}_{4}$ : synthetic diacylated and triacylated lipopeptide ligands, which mimic bacterial cell wall components recognized by TLR2/6 and TLR2/1, respectively. The results from this study suggest that $\mathrm{SiO}_{2}$ interferes with the ability of macrophages to appropriately respond to bacterial ligands by downregulating the expression of TLR2 in a CD204-dependent, but inflammasome-independent manner.

The lung is constantly exposed to potentially harmful pathogens, including airborne particulates and microorganisms. 


\section{A Bone marrow derived macrophages}
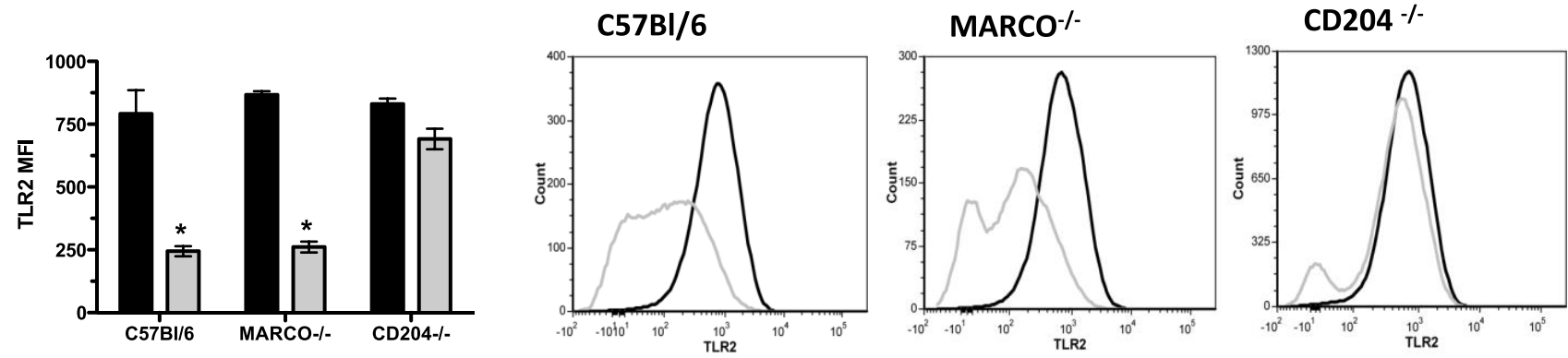

\section{B Alveolar macrophages}
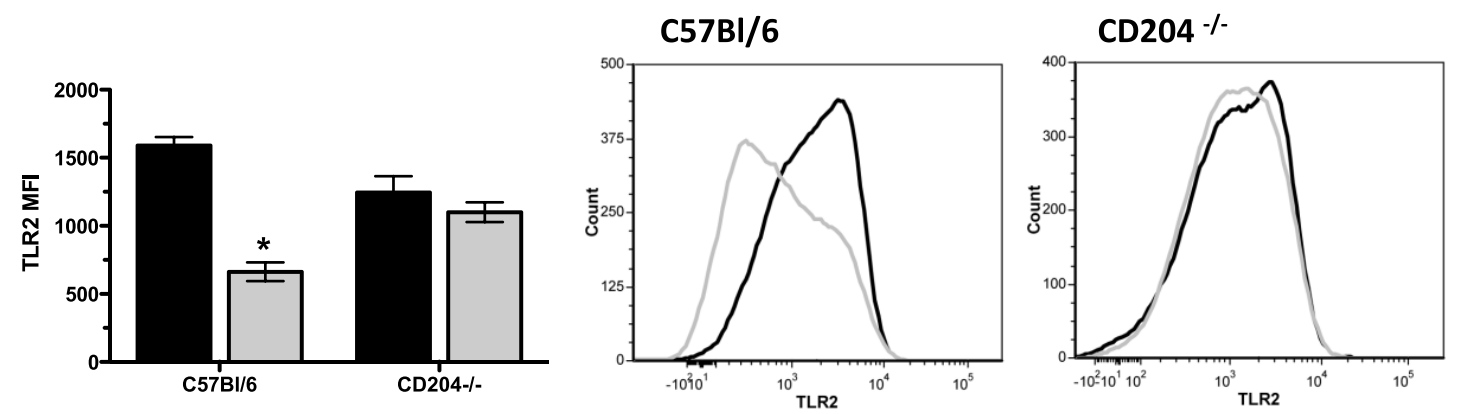

FIGURE 3 | Silica-induced decrease in TLR2 expression is dependent on the scavenger receptor CD204 in vitro and in vivo. (A) Macrophages were derived from the bone marrow of wild-type C57BI/6, CD204 ${ }^{-/}$, and $\mathrm{MACRO}^{-/-}$mice and subsequently exposed to media or silica (100 $\mu \mathrm{g} / \mathrm{ml}$ ). As anticipated, flow cytometric analysis demonstrates decreased expression of TLR2 on live, $\mathrm{F} 4-80^{+} \mathrm{CD}_{11} \mathrm{~b}^{+}$macrophages $4 \mathrm{~h}$ following exposure to $\mathrm{SiO}$. This reduction in the cell surface expression of TLR2 was dependent on the presence of the scavenger receptor CD204, but not MARCO. Results are means \pm SEM $(n=3-5)$. ${ }^{*} p<0.05$ compared to saline. Representative histograms from the flow cytometric analysis display changes in the cell surface expression of TLR2 as a function of mouse strain. (B) Wild-type C57BI/6 and CD204 ${ }^{-/-}$mice were exposed to saline (25 $\mu$ l) or silica (1 mg) through intranasal aspiration. After 4 h, whole lungs were lavaged and cells immunostained and analyzed by flow cytometry. Flow cytometry shows decreased expression of $\mathrm{TLR}_{2}$ on live, $\mathrm{F} 4-80^{+} \mathrm{CD} 11 \mathrm{bc} \mathrm{AMS}^{+} \mathrm{h}$ after $\mathrm{SiO}_{2}$, which is dependent on the presence of the scavenger receptor CD204. Results are means \pm SEM $(n=4-5)$. ${ }^{*} p<0.05$ compared to saline. Representative histograms from the flow cytometric analysis display changes in the cell surface expression of TLR2.

Numerous studies have established that macrophages (alveolar and interstitial) are key orchestrators of pulmonary immunity and the prototypical host for diverse pathogens - including $\mathrm{SiO}_{2}$ and bacterial pathogens. In the steady state, the ability of macrophages to generate an inflammatory response is tightly regulated to ensure that lung injury does not occur, thus preserving alveolar physiology and gas exchange. By contrast, in response to insult, macrophages are responsible for the uptake and clearance of a wide variety of environmental contaminants (e.g., crystalline silica), as well as phagocytizing and eliminating bacteria (e.g., $\mathrm{Mtb})$. Macrophage responses to airborne particulates and microorganisms ranges from ingestion and clearance with minimal inflammation to massive secretion of inflammatory mediators (e.g., cytokines and reactive oxygen species) and recruitment and/or activation of other innate and adaptive immune cell types. Although freshly isolated AMs most closely represent the natural state, bone marrow-derived macrophages are a widely used and accepted model system because of the relative simplicity of the isolation procedure, the high numbers of cell yielded, and the consistency of the cellular response to immune activation. In this study, both freshly isolated alveolar and bone marrow-derived macrophages were utilized to verify findings based on assay specific needs.

Alveolar macrophages are the first line of defense in the alveolar spaces against inhaled pathogens, and also serve to limit inflammation and minimize injury to preserve lung function. Because PRRs, such as C-type lectin receptors, SRs, TLRs, NODlike receptors, and RIG-I like receptors, play a prominent role in the activation of AMs and subsequent cross-talk with innate and adaptive immune cells, how a macrophage reacts to a given stimulus depends greatly on the diverse range of PRRs expressed on the cell's surface $(43,44)$. In the case of concomitant or sequential exposure to two distinct pathogens, the capacity of macrophages to recognize, phagocytose, and appropriately respond to a second stimuli may be compromised by stimulant-induced changes in the profile of PRRs (45) - thus altering susceptibility to disease. TLRs, which recognize microbial molecules, are major triggers of innate responses (e.g., enhanced costimulatory molecule expression, 

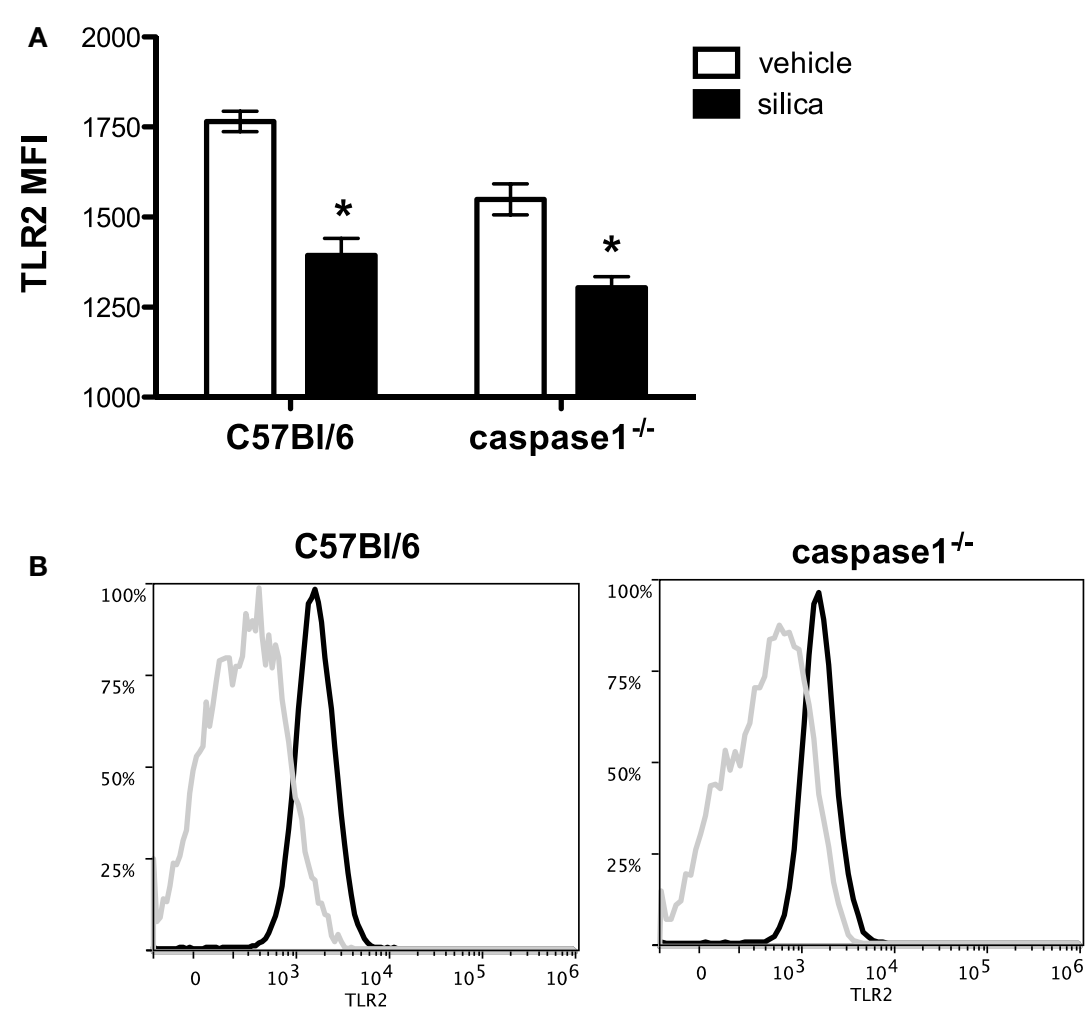

FIGURE 4 | Silica-induced reduction in TLR2 expression occurs independently of inflammasome activation. Wild-type C57BI/6 and caspase $1^{-/-}$mice were exposed to saline $(25 \mu \mathrm{l})$ or silica $(1 \mathrm{mg})$ via intranasal aspiration. After $4 \mathrm{~h}$, whole lungs were lavaged and cells immunostained and analyzed by flow cytometry using the Attune NxT acoustic focusing flow cytometer. (A) Flow cytometry corroborates decreased expression of TLR2 on live, F4-80+CD11 $\mathrm{C}^{+}$AMs isolated from $\mathrm{C} 57 \mathrm{BI} / 6$ mice $4 \mathrm{~h}$ after $\mathrm{SiO}_{2}$ and further demonstrates that this decrease is not dependent on the NLRP3 inflammasome and IL-1 $\beta$ secretion. Results are means \pm SEM ( $n=3-4$, repeated twice). ${ }^{\star} p<0.05$ compared to saline. (B) Representative histograms from the flow cytometric analysis demonstrate changes in the cell surface expression of TLR2 as a function of time.

cytokine secretion, production of reactive oxygen species, and antimicrobial mediators) and thus modulate adaptive immunity by influencing macrophage functions. TLRs are important for host responses to Mtb. In particular, TLR-2 activation has been shown to play a prominent role in eliciting appropriate immune responses to Mycobacterium avium or Mtb, as well as to bacterial products, such as lipoarabinomannan, lipoprotein, and phosphatidylinositol mannosides $(28,46-51)$. Furthermore, associations between TLR2 gene polymorphisms and tuberculosis have been reported for a range of different human populations (52, 53), suggesting that changes in TLR2 expression may be involved in susceptibility to disease. In this study, we tested the hypothesis that exposure to $\mathrm{SiO}_{2}$ triggers phenotypic changes in AMs - recognized as differences in the PRR profile. Following acute $\mathrm{SiO}_{2}$ exposure $(\leq 4 \mathrm{~h})$ in $\mathrm{C} 57 \mathrm{BL} / 6$ mice, we ascertained that live $\mathrm{F} 4-80^{+} \mathrm{CD} 11 \mathrm{c}^{+} \mathrm{AMs}$ downregulate the expression of TLR2 using multi-color flow cytometry. These results were confirmed using $\mathrm{F} 4-80^{+} \mathrm{CD} 11 \mathrm{~b}^{+}$murine bone marrow-derived macrophages, and more importantly shown to be dependent on the presence of the class A SR, CD204, but not the NLRP3 inflammasome. These findings support the importance of interactions between $\mathrm{SiO}_{2}$ and CD204 (40) and further link the $\mathrm{SiO}_{2}-\mathrm{CD} 204$ interface in macrophages to the inflammatory response to ligands acting at
TLR2. Of note, Chávez-Galán et al. recently reported that human monocyte derived macrophages and a human macrophage cell line (THP-1) also respond to $\mathrm{SiO}_{2}$ by downregulating the expression of TLR2 in a dose-dependent manner (54). Although this study did not explore the role of SRs in this process, their results suggest that $\mathrm{SiO}_{2}$ may impair the ability of human macrophages to control intracellular bacterial growth (54). These results led us to assess whether $\mathrm{SiO}_{2}$ altered the expression of other PRRs (e.g., TLR4, TLR5, TLR6, and DC-SIGN) involved in innate immunity to various pathogens. Although acute exposure to $\mathrm{SiO}_{2}$ decreased TLR6 expression on AMs, we have not yet examined whether this reduction in protein expression is dependent on CD204. These data suggest that interaction between $\mathrm{SiO}_{2}$ and CD204 may regulate the responsiveness of antigen-presenting cells to TLR2 activation. Previous studies have also observed connections between CD204 and TLR4 signaling $(55,56)$; although little is known about the biochemical nature of such interactions.

Recognition of TLR ligands results in immune activation, which can be measured as enhanced costimulatory molecule expression, cytokine secretion, production of reactive oxygen species, and antimicrobial mediators. Previous studies from our laboratory group demonstrated that $\mathrm{SiO}_{2}$ downregulates the expression of costimulatory molecules on murine bone 

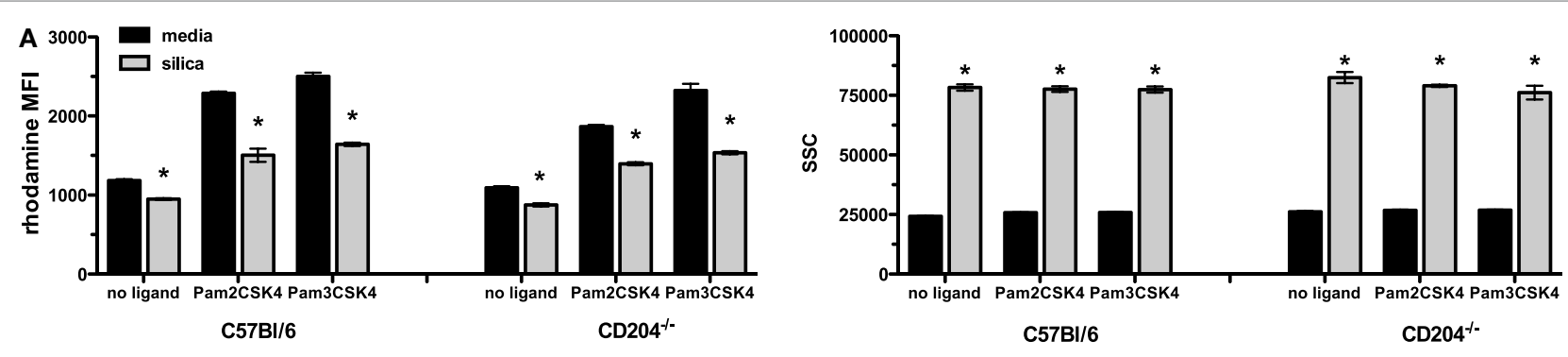

B

\section{C57BI/6}
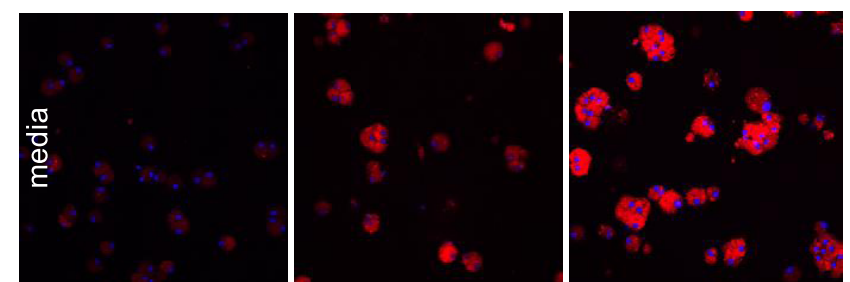

no ligand

Pam2CSK4

Pam3CSK4
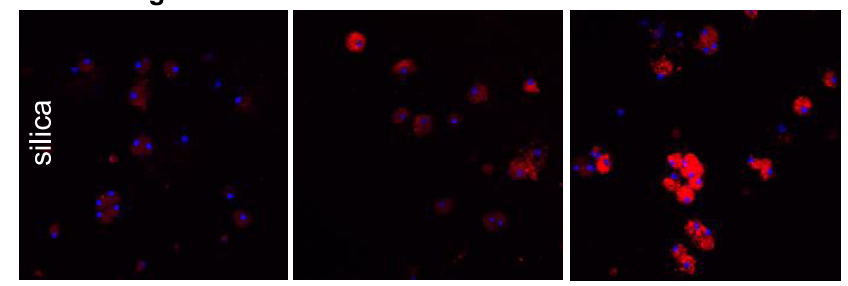

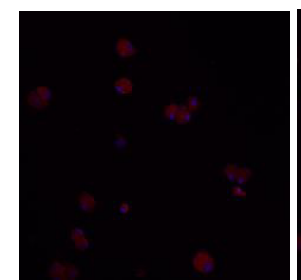

no ligand

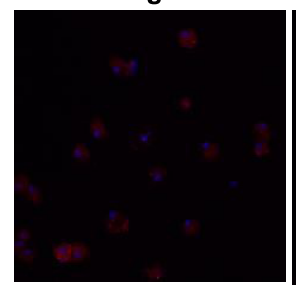

CD204--

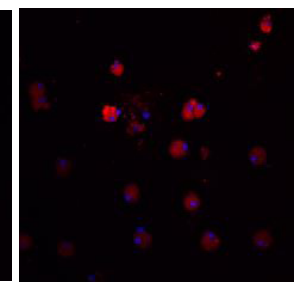

Pam2CSK4

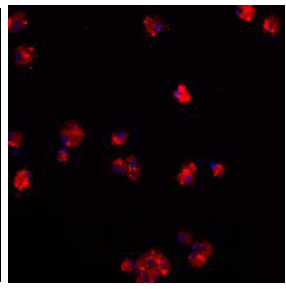

Pam3CSK4
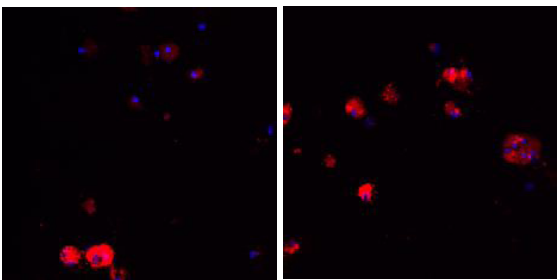

FIGURE 5 | Silica exposure decreased uptake of fluorescently labeled synthetic diacylated and triacylated lipoproteins in vitro. Macrophages derived from the bone marrow of wild-type C57BI/6 and CD204-/ mice were exposed to media or silica ( $100 \mu \mathrm{g} / \mathrm{ml})$ for $24 \mathrm{~h}$ and subsequently treated with fluorescently labeled $\mathrm{Pam}_{2} \mathrm{CSK}_{4}$ and Pam 3 CSK4 for $2 \mathrm{~h}$. (A) Flow cytometry revealed uptake of the rhomadine-labeled lipoproteins into macrophages as measured by an increase in the mean fluorescence intensity (MFI), which was attenuated in the $\mathrm{SiO}_{2}$-exposed macrophages. This increase in MFI was not due to changes in the uptake of $\mathrm{SiO}_{2}$ into the macrophages, as shown by an increase in SSC. (B) Representative images from confocal microscopy showed increased fluorescence in the macrophages exposed to fluorescently labeled lipoproteins vs. media alone. Moreover, this fluorescence was diminished in $\mathrm{SiO}_{2}$-exposed macrophages. Results are means \pm SEM $(n=5) .{ }^{*} p<0.05$ compared to media.

marrow-derived dendritic cells. These results lead us to examine whether $\mathrm{SiO}_{2}$-induced changes in TLR2 expression may result in aberrant response to bacterial ligands in vitro. Furthermore, $\mathrm{SiO}_{2}$ exposure reduced uptake of fluorescently labeled synthetic diacylated and triacylated lipoproteins recognized by TLR2/6 and TLR2/1 in both C57Bl/6 wild-type and CD204 $4^{-1-}$ derived macrophages. Several possibilities arise from this incongruity that CD204 ${ }^{-/-}$macrophages do not downregulate TLR2 expression, yet exhibit reduced ability to uptake rhodamine-labeled $\mathrm{Pam}_{2} \mathrm{CSK}_{4}$ and $\mathrm{Pam}_{3} \mathrm{CSK}_{4}$. CD204 ${ }^{-/-}$macrophages may have enhanced expression of other PRRs (e.g., biological compensation) (57), the reduced levels of TLR2 may not be responsible for changes in diacylated and triacylated ligand uptake, and $\mathrm{SiO}_{2}$ may alter signaling molecules down stream of the receptor, resulting in the same net effect. Interestingly, we also observed attenuated levels of the inflammatory cytokines IL- $1 \beta$ and TNF $\alpha$, but not IL-6, in the culture supernatants. These results are intriguing and suggest that $\mathrm{SiO}_{2}$ disrupts more downstream signal transduction events pertinent to the maturation and secretion of cytokines.

In summary, uptake of $\mathrm{SiO}_{2}$ downregulates the expression of select PRRs on AMs, as well as their ability to recognize, uptake, and respond to specific ligands. We hypothesize that these changes in AM phenotype may play a role their ability to appropriately respond to a secondary pathogen such as mycobacteria following $\mathrm{SiO}_{2}$ exposure. Our data suggest that $\mathrm{SiO}_{2}$, interacting with CD204, does not indiscriminately alter expression of all PRRs, but rather may amend signaling components involved in macrophage activation. Moreover, our data identify CD204 as an important partner for TLR2 on macrophages for the production of inflammatory mediators in response to bacterial stimuli. Future experiments may shed light on the relationship between reduced TLR2 expression and immunity to MTB infection later on.

\section{AUTHOR CONTRIBUTIONS}

$\mathrm{CB}$ designed the study, coordinated the experiments, prepared the figures, and composed the manuscript. BS performed the tissue culture, flow cytometry, and ELISA experiments under the direction of CB. FJ contributed data relative to Figures 4 and 5. GB and DS contributed to the manuscript preparation and critical revision. All authors have read and approved the final version of the manuscript. 


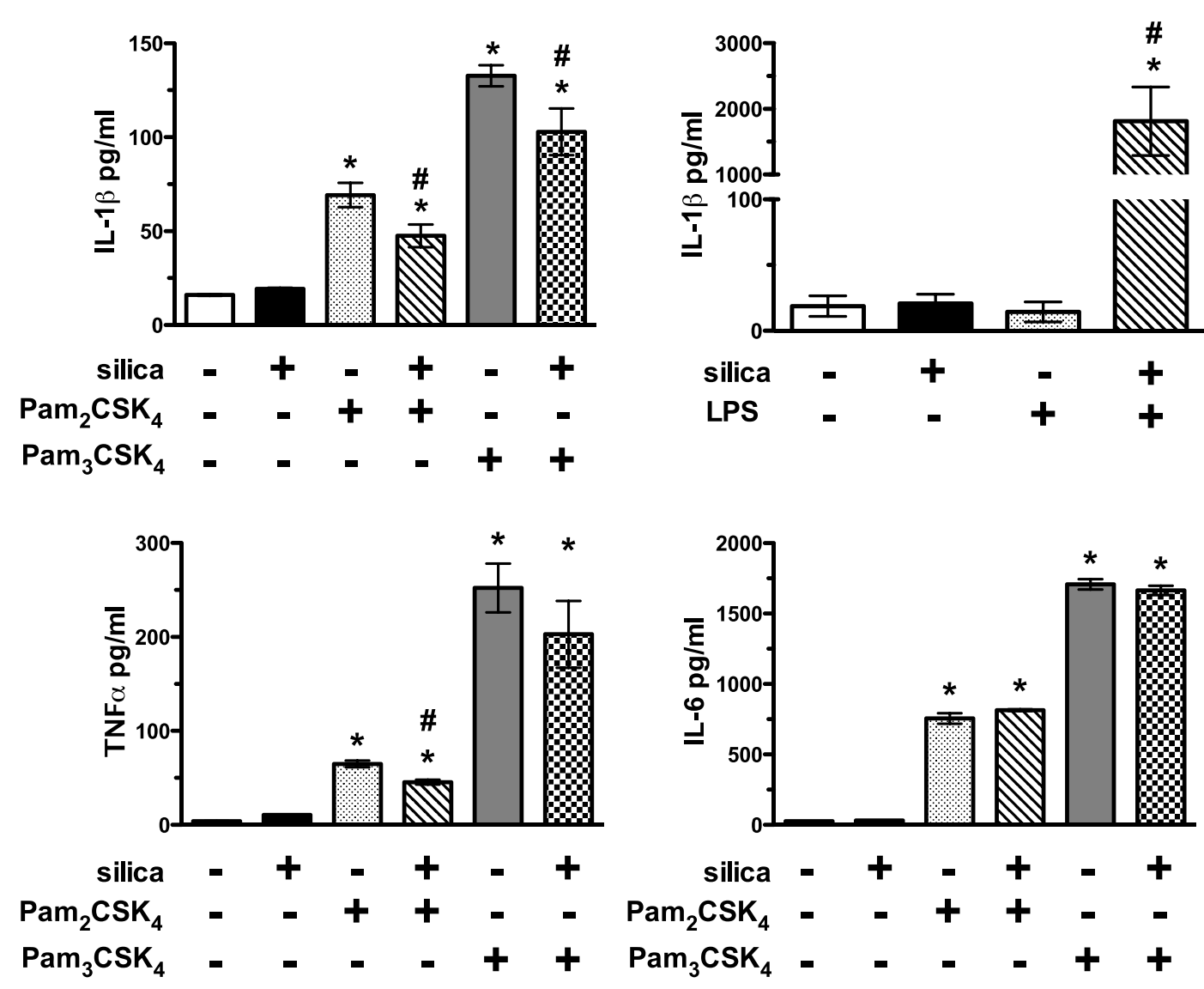

FIGURE 6 | Silica reduced IL-1ß, but not IL-6, levels in response to synthetic diacylated and triacylated lipoproteins in vitro. Macrophages derived from the bone marrow of wild-type C57BI/6 mice were exposed to media or silica (100 $\mu \mathrm{g} / \mathrm{ml})$ for 24 h and subsequently treated with fluorescently labeled Pam $\mathrm{CSK}_{4}$ and $\mathrm{Pam}_{3} \mathrm{CSK} 4$ for $2 \mathrm{~h}$. Cell-free supernatants were analyzed for the presence of the inflammatory cytokines IL-1 $\beta$ and IL-6. As expected, activation of naïve macrophages with $\mathrm{Pam}_{2} \mathrm{CSK}_{4}$ and $\mathrm{Pam}_{3} \mathrm{CSK} 4$ upregulated IL-1 $\beta$ and IL-6 levels. $\mathrm{SiO}_{2}$ alone induced a slight, but not significant, increase in IL-1 $\beta$. Although SiO ${ }_{2}$ reduced the levels of IL-1 $\beta$, it had no effect on the levels of IL-6 induced by TLR activation. Results are means \pm SEM ( $n=4)$. ${ }^{*}<0.05$ compared to media.

\section{ACKNOWLEDGMENTS}

The authors wish to thank C. Guy Goodman for his assistance in conducting these experiments during his summer undergraduate research project, as well as thank the following scientists: Lou Herritt (Molecular Histology and Fluorescence Imaging Core), Pam Shaw (Fluorescence Cytometry Core), and Britten Postma (Animal Core) for the shared expertise needed to conduct and/or analyze the experiments described in this manuscript.

\section{REFERENCES}

1. Lynch J, McCune W. Adverse effects of crystalline silica exposure. American Thoracic Society Committee of the Scientific Assembly on Environmental and Occupational Health. Am J Respir Crit Care Med (1997) 155:761-8. doi:10.1164/ajrccm.155.2.9032226

2. Parks CG, Conrad K, Cooper GS. Occupational exposure to crystalline silica and autoimmune disease. Environ Health Perspect (1999) 107:793-802. doi:10.1289/ehp.99107s5793

3. Ding M, Chen F, Shi X, Yucesoy B, Mossman B, Vallyathan V. Diseases caused by silica: mechanisms of injury and disease development. Int Immunopharmacol (2002) 2:173-82. doi:10.1016/S1567-5769(01)00170-9

\section{FUNDING}

Research reported in this publication was supported by the National Institute of General Medical Sciences of the National Institutes of Health under grant number P30-GM103338 and P20-GM103546, R25-ES016247, and R15-ES020993. The content is solely the responsibility of the authors and does not necessarily represent the official views of the National Institutes of Health.

4. Parks CG, Cooper GS, Nylander-French LA, Sanderson WT, Dement JM, Cohen PL, et al. Occupational exposure to crystalline silica and risk of systemic lupus erythematosus: a population-based, case-control study in the southeastern United States. Arthritis Rheum (2002) 46:1840-50. doi:10.1002/ art. 10368

5. Calvert GM, Rice FL, Boiano JM, Sheehy JW, Sanderson WT. Occupational silica exposure and risk of various diseases: an analysis using death certificates from 27 states of the United States. Occup Environ Med (2003) 60:122-9. doi:10.1136/oem.60.2.122

6. Wang D, Zhang M. [Statistics on notification of pneumoconiosis in China in 2010]. Zhonghua Lao Dong Wei Sheng Zhi Ye Bing Za Zhi (2012) 30:801-10. 
7. Cowie RL. The epidemiology of tuberculosis in gold miners with silicosis. Am J Respir Crit Care Med (1994) 150:1460-2. doi:10.1164/ajrccm.150.5.7952577

8. Hnizdo E, Murray J. Risk of pulmonary tuberculosis relative to silicosis and exposure to silica dust in South African gold miners. Occup Environ Med (1998) 55:496-502. doi:10.1136/oem.55.7.496

9. Corbett EL, Churchyard GJ, Clayton T, Herselman P, Williams B, Hayes R, et al. Risk factors for pulmonary mycobacterial disease in South African gold miners. A case-control study. Am J Respir Crit Care Med (1999) 159:94-9. doi:10.1164/ajrccm.159.1.9803048

10. teWaternaude JM, Ehrlich RI, Churchyard GJ, Pemba L, Dekker K, Vermeis $\mathrm{M}$, et al. Tuberculosis and silica exposure in South African gold miners. Occup Environ Med (2006) 63:187-92. doi:10.1136/oem.2004.018614

11. Delaval M, Boland S, Solhonne B, Nicola MA, Mornet S, Baeza-Squiban A, et al. Acute exposure to silica nanoparticles enhances mortality and increases lung permeability in a mouse model of Pseudomonas aeruginosa pneumonia. Part Fibre Toxicol (2015) 12:1. doi:10.1186/s12989-014-0078-9

12. Dostert C, Petrilli V, Van Bruggen R, Steele C, Mossman BT, Tschopp J. Innate immune activation through Nalp3 inflammasome sensing of asbestos and silica. Science (2008) 320:674-7. doi:10.1126/science.1156995

13. Hornung V, Bauernfeind F, Halle A, Samstad EO, Kono H, Rock KL, et al. Silica crystals and aluminum salts activate the NALP3 inflammasome through phagosomal destabilization. Nat Immunol (2008) 9:847-56. doi:10.1038/ ni. 1631

14. Yazdi AS, Guarda G, Riteau N, Drexler SK, Tardivel A, Couillin I, et al. Nanoparticles activate the NLR pyrin domain containing 3 (Nlrp3) inflammasome and cause pulmonary inflammation through release of IL-1alpha and IL-1beta. Proc Natl Acad Sci U S A (2010) 107:19449-54. doi:10.1073/ pnas. 1008155107

15. Eltom S, Belvisi MG, Stevenson CS, Maher SA, Dubuis E, Fitzgerald KA, et al. Role of the inflammasome-caspase1/11-IL-1/18 axis in cigarette smoke driven airway inflammation: an insight into the pathogenesis of COPD. PLoS One (2014) 9:e112829. doi:10.1371/journal.pone.0112829

16. Iyer R, Hamilton RF, Li L, Holian A. Silica-induced apoptosis mediated via scavenger receptor in human alveolar macrophages. Toxicol Appl Pharmacol (1996) 141:84-92. doi:10.1016/S0041-008X(96)80012-3

17. Raja A. Immunology of tuberculosis. Indian J Med Res (2004) 120:213-32.

18. Allison AC, Hart PD. Potentiation by silica of the growth of Mycobacterium tuberculosis in macrophage cultures. Br J Exp Pathol (1968) 49:465-76.

19. Zimmerman BT, Canono BP, Campbell PA. Silica decreases phagocytosis and bactericidal activity of both macrophages and neutrophils in vitro. Immunology (1986) 59:521-5.

20. Shi X, Castranova V, Halliwell B, Vallyathan V. Reactive oxygen species and silica-induced carcinogenesis. J Toxicol Environ Health B Crit Rev (1998) 1:181-97. doi:10.1080/10937409809524551

21. Shen HM, Zhang Z, Zhang QF, Ong CN. Reactive oxygen species and caspase activation mediate silica-induced apoptosis in alveolar macrophages. Am J Physiol Lung Cell Mol Physiol (2001) 280:L10-7.

22. Shi X, Ding M, Chen F, Wang L, Rojanasakul Y, Vallyathan V, et al. Reactive oxygen species and molecular mechanism of silica-induced lung injury. J Environ Pathol Toxicol Oncol (2001) 20(Suppl 1):85-93.

23. Beamer CA, Holian A. Antigen presenting cell population dynamics during murine silicosis. Am J Respir Cell Mol Biol (2007) 37(6):729-38. doi:10.1165/ rcmb.2007-0099OC

24. Cassel SL, Eisenbarth SC, Iyer SS, Sadler JJ, Colegio OR, Tephly LA, et al. The Nalp3 inflammasome is essential for the development of silicosis. Proc Natl Acad Sci U S A (2008) 105:9035-40. doi:10.1073/pnas.0803933105

25. Gilberti RM, Joshi GN, Knecht DA. The phagocytosis of crystalline silica particles by macrophages. Am J Respir Cell Mol Biol (2008) 39:619-27. doi:10.1165/rcmb.2008-0046OC

26. Hamilton RF Jr, Thakur SA, Holian A. Silica binding and toxicity in alveolar macrophages. Free Radic Biol Med (2008) 44:1246-58. doi:10.1016/j. freeradbiomed.2007.12.027

27. Giordano G, Van Den Brule S, Lo Re S, Triqueneaux P, Uwambayinema F, Yakoub Y, et al. Type I interferon signaling contributes to chronic inflammation in a murine model of silicosis. Toxicol Sci (2010) 116:682-92. doi:10.1093/ toxsci/kfq158

28. Pasula R, Britigan BE, Turner J, Martin WJ II. Airway delivery of silica increases susceptibility to mycobacterial infection in mice: potential role of repopulating macrophages. JImmunol (2009) 182:7102-9. doi:10.4049/ jimmunol.0803642

29. Janeway CA Jr, Medzhitov R. Innate immune recognition. Annu Rev Immunol (2002) 20:197-216. doi:10.1146/annurev.immunol.20.083001.084359

30. Gordon A. Pattern recognition receptors: doubling up for the innate immune response. Cell (2002) 111:927-30.

31. Geijtenbeek TB, Van Vliet SJ, Koppel EA, Sanchez-Hernandez M, Vandenbroucke-Grauls CM, Appelmelk B, et al. Mycobacteria target DC-SIGN to suppress dendritic cell function. J Exp Med (2003) 197:7-17. doi:10.1084/jem.20021229

32. Akira S, Uematsu S, Takeuchi O. Pathogen recognition and innate immunity. Cell (2006) 124:783-801. doi:10.1016/j.cell.2006.02.015

33. Bhatt K, Salgame P. Host innate immune response to Mycobacterium tuberculosis. J Clin Immunol (2007) 27:347-62. doi:10.1007/s10875-007-9084-0

34. Killick KE, Ni Cheallaigh C, O'Farrelly C, Hokamp K, Machugh DE, Harris J. Receptor-mediated recognition of mycobacterial pathogens. Cell Microbiol (2013) 15:1484-95. doi:10.1111/cmi.12161

35. Thakur SA, Beamer CA, Migliaccio CT, Holian A. Critical role of Marco in crystalline silica-induced pulmonary inflammation. Toxicol Sci (2009) 108(2):462-71. doi:10.1093/toxsci/kfp011

36. Beamer CA, Migliaccio CT, Jessop F, Trapkus M, Yuan D, Holian A. Innate immune processes are sufficient for driving silicosis in mice. J Leukoc Biol (2010) 88:547-57. doi:10.1189/jlb.0210108

37. Beamer CA, Seaver BP, Shepherd DM. Aryl hydrocarbon receptor (AhR) regulates silica-induced inflammation, but not fibrosis. Toxicol Sci (2012) 126(2):554-68. doi:10.1093/toxsci/kfs024

38. Beamer CA, Girtsman TA, Seaver BP, Finsaas KJ, Migliaccio CT, Perry VK, et al. IL-33 mediates multi-walled carbon nanotube (MWCNT)-induced airway hyper-reactivity via the mobilization of innate helper cells in the lung. Nanotoxicology (2013) 7:1070-81. doi:10.3109/17435390.2012.702230

39. Beamer CA, Holian A. Silica suppresses toll-like receptor ligand-induced dendritic cell activation. FASEB J (2008) 22:2053-63. doi:10.1096/fj.07-095299

40. Beamer CA, Holian A. Scavenger receptor class A type I/II (CD204) null mice fail to develop fibrosis following silica exposure. Am J Physiol Lung Cell Mol Physiol (2005) 289:L186-95. doi:10.1152/ajplung.00474.2004

41. Migliaccio CT, Hamilton RF Jr, Holian A. Increase in a distinct pulmonary macrophage subset possessing an antigen-presenting cell phenotype and in vitro APC activity following silica exposure. Toxicol Appl Pharmacol (2005) 205:168-76. doi:10.1016/j.taap.2004.11.005

42. Gwyer Findlay E, Hussell T. Macrophage-mediated inflammation and disease: a focus on the lung. Mediators Inflamm (2012) 2012:140937. doi:10.1155/2012/140937

43. Janeway CA Jr, Medzhitov R. Innate immune recognition. Annu Rev Immunol (2002) 20:197-216. doi:10.1146/annurev.immunol.20.083001.084359

44. Medzhitov R, Janeway CA Jr. Decoding the patterns of self and nonself by the innate immune system. Science (2002) 296:298-300. doi:10.1126/ science. 1068883

45. Arkhipov SA, Shkurupy VA, Bugrimova YS. Effect of preliminary load of macrophages with silicium dioxide on phagocytosis of BCG strain micobacteria by macrophages and antimicrobial activity. Bull Exp Biol Med (2010) 149:534-6. doi:10.1007/s10517-010-0986-0

46. Underhill DM, Ozinsky A, Smith KD, Aderem A. Toll-like receptor-2 mediates mycobacteria-induced proinflammatory signaling in macrophages. Proc Natl Acad Sci U S A (1999) 96:14459-63. doi:10.1073/pnas.96.25.14459

47. Heldwein KA, Fenton MJ. The role of toll-like receptors in immunity against mycobacterial infection. Microbes Infect (2002) 4:937-44. doi:10.1016/ S1286-4579(02)01611-8

48. Drennan MB, Nicolle D, Quesniaux VJ, Jacobs M, Allie N, Mpagi J, et al. Toll-like receptor 2-deficient mice succumb to Mycobacterium tuberculosis infection. Am J Pathol (2004) 164:49-57. doi:10.1016/S0002-9440(10)63095-7

49. Bafica A, Scanga CA, Feng CG, Leifer C, Cheever A, Sher A. TLR9 regulates Th1 responses and cooperates with TLR2 in mediating optimal resistance to Mycobacterium tuberculosis. J Exp Med (2005) 202:1715-24. doi:10.1084/ jem. 20051782

50. Kleinnijenhuis J, Joosten LA, Van De Veerdonk FL, Savage N, Van Crevel R, Kullberg BJ, et al. Transcriptional and inflammasome-mediated pathways for the induction of IL-1beta production by Mycobacterium tuberculosis. Eur J Immunol (2009) 39:1914-22. doi:10.1002/eji.200839115 
51. Mayer-Barber KD, Barber DL, Shenderov K, White SD, Wilson MS, Cheever A, et al. Caspase-1 independent IL-1beta production is critical for host resistance to Mycobacterium tuberculosis and does not require TLR signaling in vivo. J Immunol (2010) 184:3326-30. doi:10.4049/jimmunol.0904189

52. Chen YC, Hsiao CC, Chen CJ, Chin CH, Liu SF, Wu CC, et al. Toll-like receptor 2 gene polymorphisms, pulmonary tuberculosis, and natural killer cell counts. BMC Med Genet (2010) 11:17. doi:10.1186/1471-2350-11-17

53. Motsinger-Reif AA, Antas PR, Oki NO, Levy S, Holland SM, Sterling TR. Polymorphisms in IL-1beta, vitamin D receptor Fok1, and toll-like receptor 2 are associated with extrapulmonary tuberculosis. BMC Med Genet (2010) 11:37. doi:10.1186/1471-2350-11-37

54. Chávez-Galán L, Ramon-Luing LA, Torre-Bouscoulet L, Perez-Padilla R, Sada-Ovalle I. Pre-exposure of Mycobacterium tuberculosis-infected macrophages to crystalline silica impairs control of bacterial growth by deregulating the balance between apoptosis and necrosis. PLoS One (2013) 8:e80971. doi:10.1371/journal.pone.0080971

55. Yi H, Yu X, Gao P, Wang Y, Baek SH, Chen X, et al. Pattern recognition scavenger receptor SRA/CD204 down-regulates toll-like receptor 4 signaling-dependent CD8 T-cell activation. Blood (2009) 113:5819-28. doi:10.1182/ blood-2008-11-190033
56. Yu X, Yi H, Guo C, Zuo D, Wang Y, Kim HL, et al. Pattern recognition scavenger receptor CD204 attenuates toll-like receptor 4-induced NF-kappaB activation by directly inhibiting ubiquitination of tumor necrosis factor (TNF) receptor-associated factor 6. J Biol Chem (2011) 286:18795-806. doi:10.1074/ jbc.M111.224345

57. Hamilton RF Jr, Thakur SA, Mayfair JK, Holian A. MARCO mediates silica uptake and toxicity in alveolar macrophages from C57BL/6 mice. J Biol Chem (2006) 281(45):34218-26. doi:10.1074/jbc.M605229200

Conflict of Interest Statement: The authors declare that the research was conducted in the absence of any commercial or financial relationships that could be construed as a potential conflict of interest.

Copyright (C) 2016 Beamer, Seaver, Jessop, Shepherd and Beamer. This is an open-access article distributed under the terms of the Creative Commons Attribution License (CC BY). The use, distribution or reproduction in other forums is permitted, provided the original author(s) or licensor are credited and that the original publication in this journal is cited, in accordance with accepted academic practice. No use, distribution or reproduction is permitted which does not comply with these terms. 